\title{
Subterranean Values and Deviance: An Empirical Investigation of the Case of Spain
}

\author{
Gonzalo Herranz de Rafael ${ }^{1}$ and Juan Sebastián Fernández-Prados ${ }^{2, *}$ (iD \\ 1 Department of State Law and Sociology, Sociology Area, University of Malaga, 29071 Málaga, Spain; \\ gherranz@ual.es \\ 2 Department of Geography, History and Humanities, Sociology Area, CEMyRI, University of Almería, 04120 \\ Almería, Spain \\ * Correspondence: jsprados@ual.es; Tel.: +34-950-015-221
}

Received: 23 June 2018; Accepted: 27 August 2018; Published: 3 September 2018

\begin{abstract}
This study examines value similarities between deviant youth on the one hand and mainstream society on the other rather than value differences. The classic sociological research on deviance by Matza and Sykes supports this approach, given that their investigations focused more on similarities between subterranean values and the values of normal society. The General Social Survey of Spain (2016) includes 17 indicators for deviant behavior, which is the dependent variable. Likewise, it is used to define social capital and the rest of the different independent variables of the analysis. In conclusion, whereas social capital and social values were absent as causes of juvenile delinquency, the following variables explained significantly the deviant behavior among Spanish youth: tolerance towards deviance, adolescent experience, and sex. This suggests that there are at least two possible keys to improve or avoid the problem of juvenile crime: prevention or awareness programmes and new critical feminist criminology point of view.
\end{abstract}

Keywords: social values; youth; deviant behavior; social capital

\section{Introduction}

Our point of departure is the classic sociological research on deviance by Matza and Sykes (1961), who in investigating subterranean values, focused more on their similarities to rather than their divergences from the values of normal society. This approach has been adopted by other researchers (Hirschi 1969; Murdock and McCron 1983).

Ample value agreement occurs between deviants and delinquents on the one hand and broader society on the other at least in relation to the evolution of deviant behavior considered "bad" or "harmful" (Topalli 2005). Therefore, neutralization techniques (Sykes and Matza 1957), i.e., stories that justify the guilty conscience of deviants and delinquents with respect to the values accepted by all, appear to be reasonable (Huertas et al. 2016).

This study is shifted away from the unilateral focus on youth delinquency or criminal gangs that has traditionally been adopted in research investigations (Agnew 2015). Nevertheless, the variable of age cohorts is retained with special emphasis on the youngest cohort, given that the theoretical assumptions of the previously noted values were initially based on juvenile delinquency (Ulmer and Steffensmeier 2015).

Nonetheless, as argued by Mannheim (1965), a deviant and criminal subculture is not a phenomenon of young individuals in general and lower social classes, but rather that such a subculture commonly occurs in all social strata (Barron 1954). More specifically, as Matza and Sykes note while emphasizing the heterogeneity and differentiation of the values of the middle classes and the other social classes in general (1961, p. 715), "In our haste to create a standard from which deviance can be 
measured, we have reduced the value system of the whole society to that of the middle class. We have ignored both the fact that society is not composed exclusively of the middle class and that the middle class itself is far from homogeneous. Not only do different social classes differ in their values, but there are also significant variations within a class based on ethnic origins, upward and downward mobility, religion, age, etc."

The paper initiates from the assumption that the dividing lines between conventional and deviant values are tenuous, and that, first, deviant and criminal behaviors among Spaniards in general, and more particularly among the youngest, are largely determined by caricatures of commonly defended and accepted values rather than attempts to reverse such values.

Second, that deviant and criminal behaviors have greater appeal among younger individuals not as a result of exclusive values held by this group but because of the attractiveness of subterranean values, such as the search for excitement or emotion and the contempt for routine. This phenomenon is accompanied by the circumstances of idleness and consumerism that prevail in Western societies, including Spain.

A graphic example is the subterranean values of Spanish youth who oppose and negate conventional values regarding social capital. Social capital is understood as the level of trust acquired by individuals through social and economic relationships, which is translated onto the level of individual trust and cooperation with society. Portes affirms "social capital, defined as communitarianism or trust, is really a by-product of more basic structural factors of which racial homogeneity, education, and economic equality are paramount" (Portes and Vickstrom 2011). From a methodological viewpoint (developed in the paper's empirical section), social capital is typically measured using two variables: (1) the answers provided by individuals when asked whether they can trust others and (2) whether individuals participate in voluntary associations or civic activities. These areas are considered important for learning to cooperate (Banfield 1958; Putnam 2000; Inglehart 1988, 1997).

According to a study on public policy and Spanish youth (2011), the negation of Spanish youth in academics, politics, labor, and leisure reflects the strength of a social negation sustained by various agencies of information and social control.

In effect, based on this negation, the prevailing view of Spanish youth held by adults is that they indulge in irrational, risky behavior, are uninterested in politics and civic participation, are presentist and egotistic, perform poorly in school according to the Programme for International Student Assessment (PISA), lack motivation at work, are tied to ICTs, are consumerist, delay independence to avoid discomfort, and are unpresentable "neither-nor" individuals (i.e., they neither study nor work) (Comas 2011).

The results for youth social capital contradict this negative hypothesis. Both interpersonal trust and participation in secondary associations are increasing, giving rise to an increase in collective responsibility. According to 2011 data, the level of trust in others among Spanish youth 18-24 years of age was 4.63 on a scale of 1-10, while for the Spanish population, it was 4.52 (Camacho 2011).

\section{Theoretical Model, the Matza and Sykes Proposal, and Subterranean Values}

A significant contribution by Matza and Sykes (1961) is their differentiation of the different types of deviant and delinquent behavior, particularly, compulsive, committed, and episodic. The latter type is of interest. Thus, deviance or delinquency is voluntary, intentional behaviors that are both intermittent and informal, tend to have a short duration in the youth environment, and normally diminish at the commencement of adulthood.

This legitimation of delinquency, which counters previous proposals regarding delinquency's rootedness with a set of oppositional values characteristic of criminal subcultures, is affirmed by both functionalist and subcultural theories (Parsons 1942; Linton 1942; Coleman 1960; Cohen 1955; Pitts 2008) and leads to the primary contribution of such theories. That is, juvenile delinquents do not express the values of an autonomous subculture. Rather, they should be understood in terms of an 
intergenerational conflict (Bloch and Niederhoffer 1958; Mannheim 1965) that causes the subterranean values present in all social strata and classes to emerge. Supporters of this view believe that if the value system is observed carefully one finds that many theoretically criminal values closely resemble those expressed by the leisure activities of mainstream conventional society. Additionally, the continuous dialectical interconnection between subterranean and traditional values means that both sets of values are modified over time.

Young individuals normally do not adopt attitudes of antagonism or confrontation with conventional values but often act within the limits of laws and customs, with a tendency to caricature them. However, they typically share conventional values, a fact that is reflected, according to Sykes and Matza (1957), in the guilty conscience entailed by violating conventional norms. This guilty conscience gives rise to what those researchers term neutralization techniques, i.e., forms of compensating for culpability and deflecting expressions of disapproval to others. If the neutralization techniques are forms of self-defense used following episodic deviant or criminal behavior to bypass social controls, subterranean values represent a generational reinterpretation of conventional values. Such subterranean values are positioned on a spectrum that ranges from feeling emotion, excitement, and adrenaline to disdain for joining the workforce and contempt for daily monotony to ostentation, generosity in the use of money, consumerism, and aggressiveness (including the overvaluation of masculinity). All these values encourage youths to indulge in episodic forms of leisure based on violating laws or conventional norms. "In short, juvenile delinquency appears to be permeated by a cluster of values that can be characterized as the search for the adrenaline rush, the disdain of work and a desire for the big score, and the acceptance of aggressive toughness as proof of masculinity" (Matza and Sykes 1961, p. 715).

In fact, according to Matza and Sykes (1961), one of the most coherent explanations of the initiation and development of criminal or deviant activities among youth is their similarity to components of the code of Veblen's gentleman of leisure: the emphasis on daring and adventure, the rejection of the discipline of work, the taste for luxury and conspicuous consumption, and the respect paid to manhood demonstrated through force. These values are typical of the leisured elite.

It is in this similarity to leisure, together with the values of work and the articulation of violence, that the equalization of the value systems of conventional and deviant society is situated. The key to value equalization is the widely accepted view that subterranean values conflict or compete with other values.

There are many examples that suggest the value similarities between the average citizen and the deviant: the valorization of adventure; the virtues of hard work, saving, and conspicuous consumption; and the conceptualization of violence and aggression as well as toughness and masculinity.

Like the search for emotion, the valorization of adventure equates the average citizen with the deviant. Although the valorization of adventure is not one of the most important principles of the dominant social order, it is not rejected by conventional society. It persists as a motivational structure, for example, in the form of the daring and excitement of sports, in recreation, and vacation activities as well as in the search for the adrenaline "rush" of gambling, nightclubs, or nocturnal carousing. "The search for adventure, excitement and thrills, then, is a subterranean value that now often exists side by side with the values of security, routinization, and the rest" (Matza and Sykes 1961, p. 716).

Normally, the adverse structural conditions of inadequate education and limited access to the labor market lend substantial importance to idleness. Often, idleness results in deviant or criminal acts by youth.

Such acts assume different forms and involve diverse acts and meanings. The setting for such acts can be nearly anywhere: the streets, mass sporting events, or department stores. The same is true of the forms of such acts: boredom-induced conflict, street fights, or flaunting the limits of the law.

Three links can be considered to exist between deviance and crime on the one hand and delinquent episodes and diversions on the other. These relationships should not be understood as exclusive but contingent. They depend on moments, places, and options. Delinquency is a way to obtain diversion 
and leisure through the acquisition of various self-satisfactory products (Light et al. 1993; Sullivan 1989; Parker 1974). Delinquency guarantees fun and excitement (Cusson 1983). Delinquency is a subproduct of emotion and adventure (Corrigan 1979).

The combination of these three relationships demonstrates the tendency of young individuals to create diversion through violating the law and explains the episodic and banal nature of deviance and delinquency.

In short, this research coincides with Matza and Sykes' theory. Therefore, our interest in this study is to clarify whether value similarities or differences exist between deviant Spanish youth and Spanish society in general.

\section{Methods and Data}

\subsection{Objectives and Hypothesis}

On the one hand, from a descriptive perspective, the sociodemographic and socioeconomic characteristics of Spaniards who have exhibited deviant or criminal behaviors are presented. On the other, an explanatory analysis is performed using ANOVA and a logistic regression model based on a deviance index as a dependent variable to determine which independent variables best explain the behaviors of Spanish deviants and delinquents. In addition, our analysis seeks to determine whether these behaviors are bound by standard subterranean values and whether they converge with or diverge from those of mainstream Spanish society.

\subsection{Data, Sample, and Sampling}

The data analyzed in the paper were derived from the General Social Survey of Spain (Encuesta Social General de España) conducted in early 2016 by the Centre for Sociological Research (Centro de Investigaciones Sociológicas) among the Spanish population over 18 years of age. According to the survey clarification, 5290 interviews were performed in a two-stage procedure and stratified by clusters. The selection of the primary sampling units (sections) was proportional to the resident population. The selection of the secondary units (individuals) was performed based on a systematic selection of individuals residing in the section according to street address. Therefore, as a whole and based on simple random sampling, the sampling error was $\pm 1.4 \%$, the confidence level was $95.5 \%$ (two sigmas), and $\mathrm{P}=\mathrm{Q}$. For the subsample of young individuals 18-30 years of age (905 interviews), the assumed sampling error was $\pm 3.2 \%$.

\subsection{Data, Sample, and Sampling}

The questionnaire consisted of more than a hundred questions. The dependent variable was deviant behavior and consisted of 17 deviant traits or behaviors displayed during the previous 12 months. A very low prevalence was considered dichotomous, that is, displaying one or more deviant behaviors or not displaying any. Another question gathered information regarding tolerance or lack of tolerance regarding each of the 17 items. The latter variable was independent in our model, and deviant behavior and tolerance of deviance were employed dichotomously by calculating the prevalence or rate of deviance. Frequency was considered using a scale from the smallest to the largest number of deviant behaviors that were tolerated (Table 1).

The set of independent variables used in the analysis (Table 2) included the usual sociodemographic questions (i.e., sex, age, subjective social class, education, ideology, and religion). In addition, the main dimensions of social capital were incorporated (i.e., interpersonal trust, involvement in voluntary associations, and participation in civic or solidarity activities). Finally, a list of six deviant acts performed or not performed in adolescence (between 12 and 16 years of age) was considered. 
Table 1. Dependent variable.

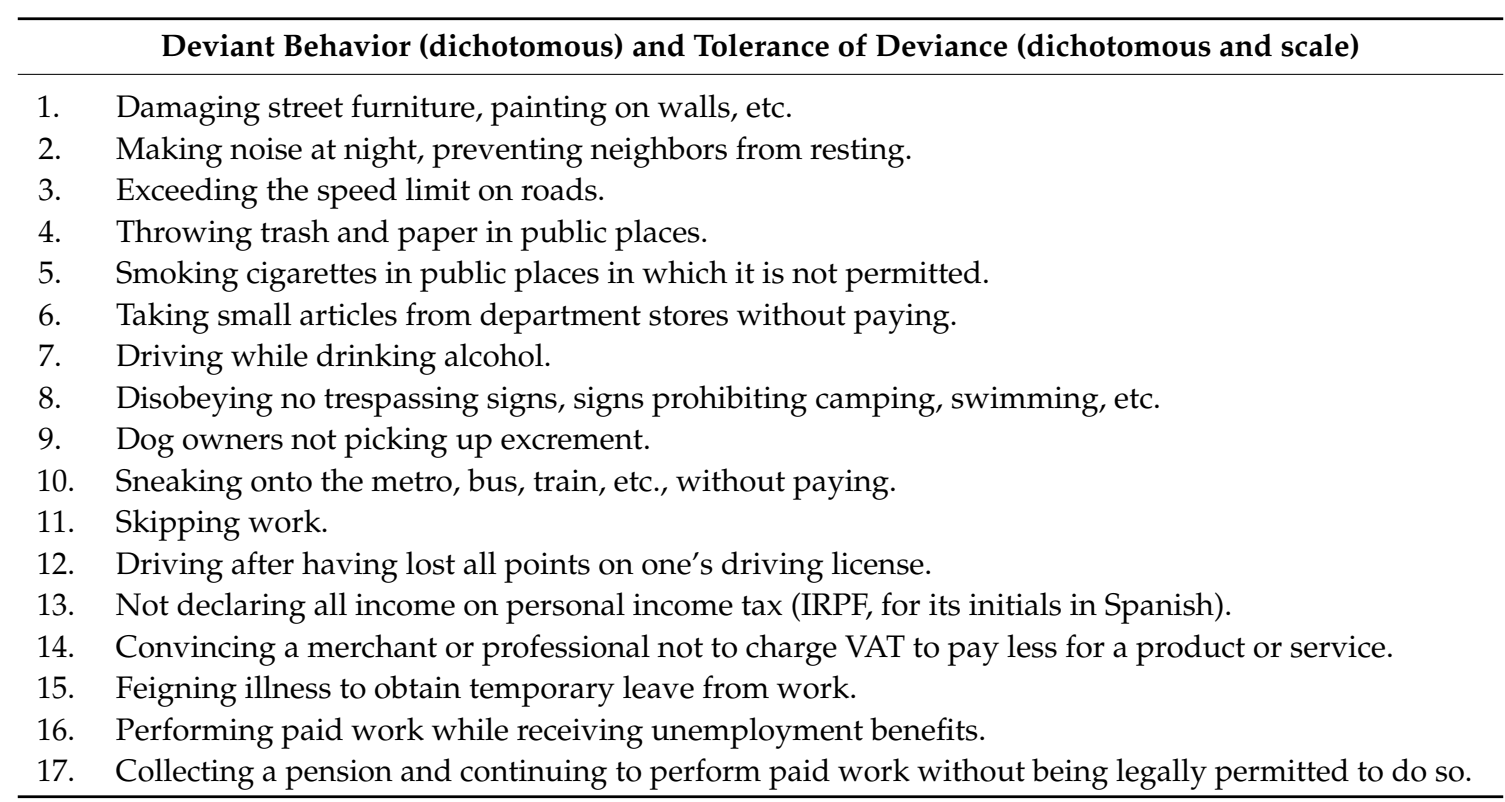

Table 2. Independent variables.

\section{Sociodemographic}

Sex, income, ideology, education, religious practice

\section{Interpersonal Trust}

1. Would you say that, in general, most people can be trusted or that one can never be too careful in dealing with others? Please rate this item on a scale of $0-10$, where 0 is "you can never be too careful" and 10 is "most people can be trusted".

\section{Activism}

1. Has given blood

2. Has donated clothes or food to needy people, whether directly or through an organization

3. Has helped or taken care of persons not in their family without charging (taken care of children or sick persons, persons without resources)

4. Has utilized the local special waste collection service ("punto limpio")

5. Has performed volunteer work, unpaid, at an NGO or association

6. Has donated to NGOs or social associations

7. Has made a contribution for cultural or artistic purposes (patronage)

\begin{tabular}{|c|c|}
\hline \multicolumn{2}{|r|}{ Associationism } \\
\hline 1. & Political associations \\
\hline 2. & Business or labor union associations \\
\hline 3. & Professional associations \\
\hline 4. & Religious associations \\
\hline 5. & Sport associations \\
\hline 6. & Cultural or leisure associations \\
\hline 7. & Social or human rights associations \\
\hline 8. & Youth or student associations \\
\hline 9. & Neighborhood associations \\
\hline 10. & Parents' associations \\
\hline 11. & Other voluntary associations \\
\hline
\end{tabular}


Table 2. Cont.

\begin{tabular}{ll}
\hline & Deviant Behavior in Adolescence \\
\hline 1. & Damaging street furniture, painting on walls, etc. \\
2. & Taking small articles from department stores without paying \\
3. & Sneaking onto the metro, bus, train, etc., without paying \\
4. & Experimenting with drugs \\
5. & Having a problem with the police (arrested or reported) \\
6. & Having violent conflicts with friends, peers, neighbors, partner \\
\hline & Tolerance of Deviance (dichotomous and scale) \\
\hline
\end{tabular}

\section{Results}

\subsection{Descriptive Analysis and Profiles}

In an initial approach to the analysis of the descriptive results, the rate of the prevalence of tolerance towards deviance and the prevalence of deviant behavior were calculated for young individuals (aged 18-30) and adults (over age 30). The objective was to obtain contextualized and comparative information regarding deviant behaviors in youth, which was our research object (Table 3).

In general terms, Spaniards display higher rates of tolerance of deviance than of engagement in deviant behavior. This fact is reflected in the more than $20 \%$ difference between the total rates of tolerance and of deviant behavior among young individuals and adults. If the overall results are compared, young individuals display more tolerance of deviance than adults (67.9\% versus $48.2 \%$ ) and more deviant behavior (45.7\% versus $26.6 \%$ ).

Among the large quantity of information provided in Table 3, it is worth highlighting the results for the most overrepresented independent variables in the case of deviant behavior among Spanish youth. Thus, an initial profile of the young individual is a male of high subjective social class, leftist ideology, secondary educational level, low religious practice, associated, more trusting and civically active, with a record of deviant behavior in adolescence and a tolerance of it. The chi-squared statistic indicates that the relationship between the variables is not significant $(p<0.05)$ for the variables of subjective social class, ideology, educational level, and interpersonal trust.

The data present several notable results, such as that the prevalence of deviant behavior is related on the one hand to sociodemographic profiles with high educational levels and subjective social classes (far from traditional social exclusion) and on the other hand to the dimensions of social capital. That is, deviance is linked to greater trust, activism, and associationism (i.e., more inclusive and conventional values and behaviors). 
Table 3. Rates of tolerance of deviance and deviant behavior among youth and adults according to independent variables.

\begin{tabular}{|c|c|c|c|c|}
\hline & \multicolumn{2}{|c|}{ 18-30 Years of Age } & \multicolumn{2}{|c|}{ Over 30 Years of Age } \\
\hline & Tolerance & Behavior & Tolerance & Behavior \\
\hline Sex & $P=0.011$ & $P=0.000$ & $P=0.000$ & $P=0.000$ \\
\hline Male & $71.6 \%$ & $52.3 \%$ & $53.3 \%$ & $33.8 \%$ \\
\hline Female & $63.7 \%$ & $38.3 \%$ & $43.6 \%$ & $20.1 \%$ \\
\hline Subjective Social Class & $\mathrm{P}=0.311$ & $P=0.235$ & $P=0.003$ & $P=0.000$ \\
\hline Low & $63.1 \%$ & $44.6 \%$ & $44.5 \%$ & $22.3 \%$ \\
\hline Middle & $68.9 \%$ & $45.1 \%$ & $50.0 \%$ & $28.7 \%$ \\
\hline High & $71.4 \%$ & $58.5 \%$ & $54.2 \%$ & $29.6 \%$ \\
\hline Ideology & $\mathrm{P}=0.802$ & $P=0.085$ & $\mathrm{P}=0.211$ & $P=0.003$ \\
\hline Left & $72.8 \%$ & $54.5 \%$ & $54.7 \%$ & $33.1 \%$ \\
\hline Centre & $68.7 \%$ & $45.9 \%$ & $51.5 \%$ & $28.6 \%$ \\
\hline Right & $71.4 \%$ & $45.9 \%$ & $49.3 \%$ & $25.5 \%$ \\
\hline Education & $P=0.017$ & $P=0.135$ & $P=0.000$ & $\mathrm{P}=0.000$ \\
\hline Elementary & $56.3 \%$ & $28.1 \%$ & $31.4 \%$ & $10.8 \%$ \\
\hline Secondary & $65.5 \%$ & $46.2 \%$ & $51.4 \%$ & $29.3 \%$ \\
\hline Higher & $73.9 \%$ & $45.2 \%$ & $58.8 \%$ & $37.3 \%$ \\
\hline Religious Practice & $P=0.308$ & $P=0.025$ & $P=0.000$ & $P=0.000$ \\
\hline Low & $68.8 \%$ & $47.6 \%$ & $52.8 \%$ & $31.3 \%$ \\
\hline Middle & $60.7 \%$ & $32.9 \%$ & $38.1 \%$ & $18.2 \%$ \\
\hline High & $70.2 \%$ & $39.6 \%$ & $40.5 \%$ & $16.0 \%$ \\
\hline Associationism & $P=0.009$ & $\mathrm{P}=0.000$ & $P=0.000$ & $\mathrm{P}=0.000$ \\
\hline Not associated & $65.0 \%$ & $41.2 \%$ & $44.0 \%$ & $21.8 \%$ \\
\hline Associated & $73.5 \%$ & $53.6 \%$ & $55.3 \%$ & $34.3 \%$ \\
\hline Trust & $P=0.353$ & $\mathrm{P}=0.428$ & $\mathrm{P}=0.000$ & $\mathrm{P}=0.000$ \\
\hline Does not trust & $65.7 \%$ & $43.6 \%$ & $39.4 \%$ & $20.2 \%$ \\
\hline Trusts & $68.8 \%$ & $46.4 \%$ & $52.1 \%$ & $29.5 \%$ \\
\hline Activism & $P=0.003$ & $P=0.005$ & $P=0.001$ & $P=0.000$ \\
\hline Little or none & $62.4 \%$ & $40.3 \%$ & $44.9 \%$ & $22.6 \%$ \\
\hline A lot or some & $71.9 \%$ & $49.7 \%$ & $50.3 \%$ & $29.2 \%$ \\
\hline Deviant Adolescence & $P=0.000$ & $P=0.000$ & $P=0.000$ & $P=0.000$ \\
\hline Not deviant & $58.8 \%$ & $32.7 \%$ & $41.8 \%$ & $20.1 \%$ \\
\hline Deviant & $84.1 \%$ & $68.7 \%$ & $72.2 \%$ & $51.0 \%$ \\
\hline Tolerance of Deviance & & $P=0.000$ & & $\mathrm{P}=0.000$ \\
\hline No & & $24.5 \%$ & & $13.8 \%$ \\
\hline Yes & & $55.7 \%$ & & $40.4 \%$ \\
\hline Total & $67.9 \%$ & 45.7 & $48.2 \%$ & $26.6 \%$ \\
\hline
\end{tabular}

\subsection{Explanatory Analysis and Logistic Regression}

The binary multivariate logistic regression enables us to evaluate how the dependent variable displays or does not display deviant behaviors in the last 12 months among Spanish youth, for which the independent variables are presumably related, and to construct a model or equation for predictive purposes. The independent variables are those in the descriptive analysis considered continuous variables except sex, associationism, and deviance in adolescence, which were treated as categorical (man/woman; associated or not, deviant behaviors in adolescence or not). The latter two variables were dichotomized because of their low prevalence. Only 35\% of Spanish youth belong to an association, and only $36.1 \%$ displayed deviant behavior during adolescence.

The following Table 4 highlights three statistically significant variables in the model: sex, deviance in adolescence, and tolerance of deviance. In order of importance according to the Wald test, these 
three significant variables in the regression model are "tolerance of deviance" followed by "deviance in adolescence" and "sex". The explanatory importance of "tolerance of deviance" for deviant behavior has been observed in pioneering and recent studies, in which it has helped researchers understand and discriminate among juvenile groups that are more sensitive to deviance (Durant and Chan 1980; Young et al. 2012; Smith et al. 2018).

Table 4. Logistic regression analysis.

\begin{tabular}{lcccccc}
\hline & B & S.E. & Wald & df & Sig. & Exp(B) \\
\hline Sex (Cat) & 0.516 & 0.181 & 8.098 & 1 & 0.004 & 1.675 \\
Age & -0.037 & 0.027 & 1.814 & 1 & 0.178 & 0.964 \\
Subjective Social Class & 0.010 & 0.079 & 0.017 & 1 & 0.897 & 1.010 \\
Ideology & -0.039 & 0.045 & 0.756 & 1 & 0.385 & 0.962 \\
Education & -0.023 & 0.037 & 0.384 & 1 & 0.535 & 0.977 \\
Religious Practice & -0.106 & 0.089 & 1.399 & 1 & 0.237 & 0.900 \\
Association (Cat) & -0.291 & 0.191 & 2.305 & 1 & 0.129 & 0.748 \\
Trust & 0.047 & 0.046 & 1.045 & 1 & 0.307 & 1.048 \\
Activism & 0.068 & 0.058 & 1.376 & 1 & 0.241 & 1.070 \\
Deviant Adolescence (Cat) & 1.173 & 0.192 & 37.350 & 1 & 0.000 & 0.309 \\
Tolerance of Deviance (scale) & 0.317 & 0.052 & 37.423 & 1 & 0.000 & 1.373 \\
Constant & 0.848 & 0.885 & 0.919 & 1 & 0.338 & 2.335 \\
\hline
\end{tabular}

The remaining variables are not significant, including the remaining sociodemographic variables (i.e., age, subjective social class, or education), those that concern ideology and religion, and those that concern social capital and are associated with participation, involvement, or commitment. Specifically, the three variables of social capital exhibit beta signs in opposite directions, e.g., associated is negative while trust and activism are positive. In any case, the omnibus test is highly statistically significant $(p<0.000)$. However, according to our model, the proportion of explained variation of displaying deviant behavior among Spanish youth is not excessively high: between 20.2\% (Cox and Snell R Square) and 26.9\% (Nagelkerke R Square).

If the analysis is focused on the three explanatory variables of the deviant behavior-sex, deviant adolescence, and tolerance of deviance - the highest probability of having a deviant behavior reaches $75 \%$ among young men, with deviant behavior in adolescence and tolerance towards crime (see Table 5); on the contrary, the lowest (10\%) corresponds to adult women, without experience in adolescence and no tolerance towards deviant behaviors. Also, the 18-30 years-of-age group presents a greater probability than over 30 years of age, which increases the concern about the youth population and delinquency (Krohn and Lane 2015).

Table 5. Probability to have deviant behavior.

\begin{tabular}{cccc}
\hline & $\begin{array}{c}\text { 18-30 Years } \\
\text { Of Age }\end{array}$ & $\begin{array}{c}\text { Over 30 } \\
\text { Years of Age }\end{array}$ & Total \\
\hline Male, deviant adolescence and tolerance of deviance. & $75 \%$ & $62 \%$ & $66 \%$ \\
Female, not deviant adolescence and not tolerance of deviance & $17 \%$ & $10 \%$ & $11 \%$ \\
\hline Total & $46 \%$ & $27 \%$ & $30 \%$ \\
\hline
\end{tabular}

\section{Discussion}

Classic empirical studies (Blomberg et al. 2017) appear to confirm Matza and Sykes' theory (Downes 1966; Wilmott 1966). They demonstrate that the characteristics of juvenile delinquency accepted by most subculture research (e.g., the tendency to organize into gangs with leadership, hierarchies and a sense of belonging; value and normative duality; frustration regarding status; group cultural conflict; destructive negativity) are not observed in the responses of the studied youth. 
These young individuals largely describe deviant and criminal behaviors that are more episodic than compulsive or committed, such as vandalism, fights, car theft, and other types of theft. This outcome indicates that deviant and criminal behaviors could be better explained as life events than as a way of organizing life. The most commonly stated reasons for their criminal activity focused on boredom, idleness, and a lack of money to "do things".

Regarding limits but also coincidences, a recent study (Densley and Steven 2015) applied qualitative techniques using in-depth or semi-structured interviews of 69 mostly black young informants from different districts in London who belonged to street gangs ${ }^{1}$ to examine how such individuals choose their actions and construct their identities (Hallsworth and Young 2008). The study concluded that "drift" was an insufficient explanation for the actions of gang members".

However, the same authors state that the combination of Matza and Sykes' subterranean values and Giddens's concept of structuration represents a useful explanatory tool with respect to how and why young individuals who live in socioeconomically disadvantaged urban environments seek gang association to perform violent acts.

According to the authors, in the interpretation of their data, the causes are closer to the interpretation by Giddens (1984) based on the concept of structuration than Matza's "drift" (1964). "From our interviews, it became clear that the interplay of motivations with social and cultural resources was crucial in explaining both who wants to join a gang and who goes on to actually develop a gang career. This combination of motivated choice with material constraint fits better with Giddens' (1984) concept of 'structuration' than it does with Matza's (1964) notion of 'drift'" (Densley and Steven 2015, p. 110). However, the same researchers believe that their informants adhere to the values of the rest of society but that their entry into the gang structure is conditioned by their experiences of social exclusion, racism, and violent victimization.

The multiple marginality described by Vigil (1988), such as spatial confinement within disadvantaged barrios (neighborhoods), the lack of employment faced by black youths once school ends, the absence of legitimate opportunities and a favorable cultural context, and the victimization of these groups by the police, motivated gang membership and criminal and violent acts.

Another limit is the underprediction of "drift" or episodic behaviors in their more violent forms. Although in this case Matza (1964) ascribes "drift" to despair, the statistical evidence appears to contradict this gap, as demonstrated by studies using self-report (West and Farrington 1977; Belson 1975; Densley and Steven 2015).

According to Downes and Rock (2016), based on data from the Home Office Statistical Bulletin, by 28 years of age, $30 \%$ of men in England and Wales had appeared in court. In addition, although the majority of those who commit crimes could be ascribed to Matza and Sykes' model of "drift" delinquents, there is a small minority (approximately $6 \%$ ) of repeat offenders, and it is estimated that they are responsible for two-thirds of all crimes.

Another limitation suggested by Matza and Sykes, which was previously mentioned, was that deviance or delinquency is voluntary, intentional behaviors, but at the same time, intermittent and

1 According to Hallsworth (2013), gangs have recently become the centre of street violence in Great Britain. A news article from Diario ABC cites data that indicate that so far this year there have been 55 deaths (versus 54 in New York) (9/4/2018::32, "Street gangs turn London into crime capital" ["Las bandas callejeras convierten Londres en la capital del crimen"]). According to the head of the Scotland Yard, Cressida Dick, the problem of street gangs was formerly centred in East London, specifically Hackney, but now has expanded throughout the city, with gangs that control drug trafficking and recruit socially marginalized and economically troubled youths and adolescents every day through social networks. For a proposed solution that involves all affected society (Spergel 2007; Howell and Griffiths 2016).

2 In addition to gang aetiology and identity, this article explains through informant narratives three classic components of the gang problem: poverty, violence, and racism. Although with lesser detail, the difficult questions of gender and social class are also addressed. More specifically, the informants describe their lives in the terms that Vigil (1988) termed "multiple marginality" and what Macquant (2007) describes as subjugation to three forces: mass unemployment, confinement to marginal or neglected neighbourhoods, and social class or ethnic stigmatization. We will encounter these aspects again later. This same interpretive line is applied to thieves in Chile by Cooper (2005), who critiques Matza's proposal, his neutralization techniques, and the concept of subterranean values (see page 44 and following). 
informal. They often have a short duration in the youth environment and normally diminish at the onset of adulthood.

Other studies (Budd et al. 2005) on England and Wales demonstrate that abandonment of criminality does not always occur by a certain age. While $60 \%$ of delinquents were younger than 25 years of age, $40 \%$ were over 25 .

In the case of Spain, according to data from the National Institute of Statistics (Instituto Nacional de Estadística or INE), a total of 365,202 crimes were committed in 2016. Of them, 141,200 were committed by young individuals aged $18-30$ years (i.e., 38.7\%), while other age groups were responsible for 224,002 crimes $(61.34 \%)$. However, it should be noted that the age group to which the greatest number of crimes is attributed is that of ages $41-50(74,091)$.

If the incidence of crime is observed by offense type and perpetrator age in Spain, the tendency remains the same. That is, except for property crime, young individuals continue to commit fewer crimes than adults, particularly those which Matza and Sykes established as more episodic in nature, such as robbery $(65.5 \%)$, armed robbery $(57 \%)$, burglary $(56.3 \%)$, car theft $(58.4 \%)$, seizure $(54.7 \%)$, and receiving and laundering money $(52.7 \%)$, the latter being the only crime that is outside the model. However, even for the group of crimes that includes property crime (i.e., the most common type committed by youths), youths were responsible for $47.30 \%$ of the total number versus $52.70 \%$ committed by adults.

\section{Conclusions}

The overall results of our survey demonstrate a large difference of nearly $20 \%$ between the youth population (i.e., the population under 30 years of age) and the adult population over 30 years of age in deviant behavior and tolerance of deviance. This drift towards deviant behavior, a prelude to delinquency, and permissiveness towards such behavior among Spanish youth has a generational component that indicates a strong coherence among the theories of Giddens and Matza and Sykes, previous research, statistical data, and our survey.

The scarce or absent relationship between the sociodemographic variables (except sex) and the components of social capital with respect to deviant behaviors among Spanish youth initially reaffirms the idea that certain deviant behaviors are supported by all types of profile and social value. Even the main sociodemographic profiles of young individuals who have exhibited deviant behavior differ fundamentally from those of socially excluded groups (e.g., based on social class or low educational level) or those who entertain antisocial values (e.g., not trusting people, not being socially involved).

Our study highlights three variables for understanding the cause of deviant behavior among Spanish youth: being tolerant of these behaviors, exhibiting deviance in adolescence, and belonging to the male sex. Additionally, in our model, the traditional values associated with ideology and religion as well as variables of social capital linked with associationism, activism, and interpersonal trust do not significantly explain the study variable or the dependent variable. This outcome again confirms the hypothesis that certain values do not fundamentally differ between those who display deviant behavior and those without social capital, at least for those individuals analyzed in our study. From a substantive perspective, social capital concerns the expectations, norms, and values that Inglehart associated with the culture of trust and postmaterialist values.

Although these findings must be replicated before taking the data as valid, reliable, and generalizable, if tolerance towards deviance, adolescent experience, and sex are considered, according to the data, to be the main factors to understand the deviant behavior, there are at least two possible keys to improve or avoid that social problem: prevention or awareness programmes and new critical feminist criminology point of view.

Primary prevention refers to actions taken to avoid the initial development of the broader social issues related to deviance. Developmental prevention focuses on risk factors that may lead individuals to deviant behavior. While it may be possible to target just children or adolescents, many developmental interventions work with large groups of potentially at-risk individuals or 
with situations that engender high risk. Programmes working with parents and children to build parental and social skills, preparation for school, cognitive abilities, and more are prime examples of developmental approaches (Lab).

Classic delinquency theory focused entirely on the role of class and urban subculture as the producing milieu of delinquency. This had the result of regularizing male violence, ignoring girls' victimization, and the role it plays in traditional female "delinquency", also allowed to miss the sexism that permeated the juvenile justice system. The insights of critical feminist criminology point to the need for a delinquency theory that consciously theorizes both gender and patriarchy and to do so on a more global stage (Chesney-Lind and Chagnon 2016).

Author Contributions: Conceptualization, G.H.R.; Formal analysis, J.S.F.; Methodology, J.S.F.; Writing - original draft, G.H.R.; Writing - review \& editing, J.S.F.

Funding: This research received no external funding.

Conflicts of Interest: The authors declare no conflict of interest.

\section{References}

Agnew, Robert. 2015. Juvenile Delinquency: Causes and Control. New York: Oxford University Press.

Banfield, Edward C. 1958. The Moral Basis of a Backward Society. Chicago: Free Press.

Barron, Milton L. 1954. The Juvenile Delinquent Society. New York: Alfred A Knopt.

Belson, William A. 1975. Juvenile Theft: The Causal Factors. London: Harcourt Brace College Publishers.

Bloch, Herbert, and Arthur Niederhoffer. 1958. The Gang: A Study of Adolescent Behavior. New York: Philosophical Library.

Blomberg, Thomas G., Francis T. Cullen, Christoffer Carlsson, and Cheryl Lero Johnson. 2017. Delinquency and Drifts Revised. The Criminology of Davis Matza and Beyond. London: Routledge.

Budd, Tracey, Clare Sharp, and Pat Mayhew. 2005. Offending in England and Wales: First Result from the 2003 Crime and Justice Survey. London: Home Office.

Camacho, José M. 2011. Principales retos de las políticas de juventud. Revista de Estudios de Juventud 94: 49-67.

Chesney-Lind, Meda, and Nicholas Chagnon. 2016. Criminology, Gender, and Race: A Case Study of Privilege in the Academy. Feminist Criminology 11: 311-33. [CrossRef]

Cohen, Albert K. 1955. Delinquent Boys: The Culture of the Gang. Chicago: Free Press.

Coleman, James S. 1960. The Adolescent Society: The Social Life of Teenager and Its Impact on Education. New York: Free Press.

Comas, Domingo. 2011. ¿Por qué son necesarias las políticas de juventud? Revista de Estudios de Juventud 94: $11-27$.

Cooper, Doris. 2005. Delincuencia y desviación juvenil. Santiago de Chile: LOM.

Corrigan, Paul. 1979. Schooling the Smash Street Kids. London: Macmillan.

Cusson, Maurice. 1983. Why Delinquency. Toronto: University of Toronto Press.

Densley, James A., and Alex Steven. 2015. We'll show you gang': The subterranean structuration of gang life in London. Criminology and Criminal Justice. 15: 102-20. [CrossRef]

Downes, David. 1966. The Delinquent Solution: A Study in Subcultural Theory. London: Routledge and Kegan Paul.

Downes, David, and Paul Rock. 2016. Understanding Deviance: A Guide to the Sociology of Crime and Rule-Breaking. Oxford: Oxford University Press.

Durant, Thomas J., Jr., and Cecilia Chan. 1980. Social tolerance for crime and deviance: An exploratory analysis. Deviant Behavior 1: 261-80. [CrossRef]

Giddens, Anthony. 1984. The Constitution of Society: Outline of the Theory of Structuration. Berkeley: University of California Press.

Hallsworth, Simon. 2013. The Gang and Beyond: Interpreting Violent Street Worlds. Basingstone: Palgrave Macmilla. Hallsworth, Simon, and Tara Young. 2008. Gang talk and gang talkers: A critique. Crime Media Culture 4: 175-95. [CrossRef]

Hirschi, Travis. 1969. Causes of Delinquency. Berkeley: University of California Press.

Howell, James C., and Elizabeth Griffiths. 2016. Gangs in America's Communities, 2nd ed. Sage: Los Angeles. 
Huertas, Omar, Nadia M. Díaz, and José S. Trujillo. 2016. David Matza: Perspectiva criminológica de la deriva a la delincuencia juvenil. Revista Criminalidad 58: 49-60.

Inglehart, Ronald. 1988. Cultura política y democracia estable. Revista Española de Investigaciones Sociológicas 42: 45-65. [CrossRef]

Inglehart, Ronald. 1997. Modernization and Postmodernization: Cultural, Economic, and Political Change. Princeton: Princeton University.

Krohn, Marvin D., and Jodi Lane. 2015. The Handbook of Juvenile Delinquency and Juvenile Justice. Oxford: Wiley Blackwell.

Lab, Steven P. Crime Prevention. Approaches, Practices, and Evaluations. London: Routledge.

Light, Roy, Claire Nee, and Helen Ingham. 1993. Car Theft: The Offender's Perspective. London: HMSO.

Linton, Ralph. 1942. Age and sex categories. American Sociological Review 7: 589-603. [CrossRef]

Macquant, Loïc. 2007. Urban Outcasts. A Comparative Sociology of Advanced Marginality. Cambridge: Polity Press. Mannheim, Hermann. 1965. Comparative Criminology. London: Routledge-Kegan Paul.

Matza, David. 1964. Delinquency and Drift. New York: Wiley.

Matza, David, and Gresham Sykes. 1961. Juvenile delinquency and subterranean values. American Sociological Review 26: 712-19. [CrossRef]

Murdock, Graham, and Robin McCron. 1983. Consciousness of class and consciousness of generation. In Resistance through Rituals Youth Subcultures in Post-Ward Britain. Edited by Stuart Hall and Tony Jefferson. London: Hutchinson University Library, pp. 192-207.

Parker, Howard. 1974. The View from the Boys. Newton Abbot: Davis and Charles.

Parsons, Talcott. 1942. Age and sex in the social structure of the United States. In Essays in Sociological Theory. Edited by Talcott Parsons. New York: Free Press, pp. 89-102.

Pitts, John. 2008. Reluctant Gangsters. The Changing Face of Youth Crime. Cullompton: Willan Publishing.

Portes, Alejandro, and Erik Vickstrom. 2011. Diversity, social capital and cohesion. Annual Review of Sociology 37: 461-79. [CrossRef]

Putnam, Robert. 2000. Bowling Alone: The Collapse and Revival of American Community. New York: Simon and Schuster.

Smith, Sven, Zenta E. Gomez, and Chris Ferguson. 2018. Social Learning, Social Disorganization, and Psychological Risk Factors for Criminal Gangs in a British Youth Context. Deviant Behavior. Advance online publication. Available online: https:/ / doi.org/10.1080/01639625.2018.1438059 (accessed on 23 June 2018).

Spergel, Irving A. 2007. Reducing Youth Gang Violence. The Little Village Gang Project in Chicago. Plymouth: Altamira Press.

Sullivan, Mercer L. 1989. "Getting Paid": Youth Crime and Work in the Inner City. New York: Cornell University Press. Sykes, Gresham H., and David Matza. 1957. Techniques of Neutralization: A theory of delinquency. American Sociological Review 22: 664-70. [CrossRef]

Topalli, Volkan. 2005. When being good is bad: An expansion of neutralization theory. Criminology 43: 797-835. [CrossRef]

Ulmer, Jeffery T., and Darrell J. Steffensmeier. 2015. The age and crime relationship: social variation, social explanations. In The Nature versus Biosocial Debate in Criminology: On the Origins of Criminal Behavior and Criminality. Edited by Kevin M. Beaver, J. C. Barnes and Brian B. Boutwell. Thousand Oaks: Sage, pp. 337-96. Vigil, James D. 1988. Barrio Gang: Street Life and Identity in Southern California. Austin: University Texas Press.

West, Donald J., and David P. Farrington. 1977. The Delinquent Way of Life. London: Heinemann.

Wilmott, Paul. 1966. Adolescent Boys in East London. London: Harmondsworth.

Young, Susan, Eric Taylor, and Gisli Gudjonsson. 2012. Childhood Predictors of Criminal Offending. Journal of Attention Disorders 20: 206-13. [CrossRef] [PubMed]

(C) 2018 by the authors. Licensee MDPI, Basel, Switzerland. This article is an open access article distributed under the terms and conditions of the Creative Commons Attribution (CC BY) license (http:/ / creativecommons.org/licenses/by/4.0/). 